\title{
The effect of public expenditures on economic growth of Kosovo: An econometric analysis
}

\section{Florije Miftari $\mathbb{D}^{\mathbb{C}}$, Nakije Kida $(\mathbb{D}$, Nuhi Shala}

Faculty of Economics, AAB College, Kosovo

florije.miftari@universitetiaab.com; nakije.kida@universitetiaab.com; nuhi.shala@universitetiaab.com

\begin{tabular}{l}
\hline OPEN $O$ ACCESS CC dol \\
\hline Article history: \\
Received: February 11, \\
2021 \\
1st Revision: March 09, \\
2021 \\
Accepted: April 11, 2021 \\
\hline JEL classification: \\
C01 \\
E62 \\
F43 \\
\hline D0I: \\
10.14254/jems.2021.6-1.5
\end{tabular}

Abstract: Public spending as an important component of the composition of GDP has an impact on economic growth and development. The main purpose of this paper is to analyze the effects of disaggregated public expenditures, to measure the impact of current expenditures, transfers and subsidies, and capital expenditures as part of total government expenditures on economic growth and development of the Republic of Kosovo. To achieve the main goal of the paper was used the multiple linear regression model (OLS) and Pearson. The regression model has been modified and adapted to measure the regression of public spending on economic growth in Kosovo. The data used in the paper are secondary and collected from the Ministry of Finance of Kosovo, Agency of Statistics, and the Tax Administration of Kosovo. Data processing was done with SPSS. The results of the analysis show that the trend of Kosovo public spending for the analyzed period is increasing. According to Pearson correlation analysis, the results show that current public spending; transfers, and subsidies have a strong positive correlation to Gross Domestic Product. Whereas capital (investment) expenditures have a weaker positive correlation with GDP. The results of OLS regression, in our case, did not show the significance of independent variables, which means that the pubic expenses do not have an impact on economic growth in Kosovo.

Keywords: public spending, economic growth, GDP, Kosovo, fiscal policy. 


\section{Introduction}

Effects or impact of public spending on economic growth and development, have always been and continued to be well nowadays an issue that has attracted the attention of researchers, economists, and policy-makers. The purpose of many studies based on the theoretical aspects of the impact of public spending on growth or development is to measure this impact. According to classical and neoclassical economic theory the effects of expenditures and government revenues, have a negative impact on growth and development as a result of the crowding-out effect. But after the Great Depression and World War I, public finances underwent substantial, quantitative, and qualitative changes expressed in increasing public spending; expanding and strengthening the role of public spending in promoting growth and full employment. The realization of modern concepts on public finances and the formation of fiscal policy is linked to the so-called "Keynesian revolution". According to Keynes (1936), insufficient demand is an immanent phenomena, and that the problem of unemployment as a result of insufficient demand is a permanent problem of the system. Therefore, the task of the state is to ensure that level of aggregate demand will correspond to the level of national income during full employment. Fiscal policy in this sense must be adapted to the need to create additional investment demand and consumer demand, with the help of public policy and increased government spending. Strengthening aggregate demand with monetary and fiscal activities even above the level of real income. Although this may trigger inflationary trends, Keynes believes that, if inflation is kept in check, it cannot affect financial stability.

In developing countries, the shift in public spending is not only to ensure economic stability but also to generate and accelerate economic growth and promote employment opportunities.

Increasing spending can be beneficial for a country's economy. In line with economic theories, the increase in government spending has a positive effect on economic growth through the multiplier effect, which results in increased aggregate demand for goods and services, which helps increase production and employment. All this is accompanied by higher economic growth in the short run.

In the structure of the GDP of Kosovo, government spending does not have a high share compared to other developing countries, but the upward trend is based on GDP growth. Thus in 2010, the share of government expenditures in GDP is $24.4 \%$ reaching the level of $29.5 \%$ in 2019.

The main strategic objective of the Government of Kosovo is the macroeconomic and fiscal stability of the country, which is a precondition for the functioning of government activities and the creation of a more favorable climate for the development of the private sector. Planned fiscal policies support economic growth and the structural reform agenda, ensuring that public investment expenditures reach over $10 \%$ of GDP, and focus on improving transport infrastructure, as well as investments in education and health institutions, agriculture and rural development, irrigation and wastewater treatment.

In capital expenditures, priority is given to activities that have an impact on long-term economic development, including public infrastructure and investments with an impact on private sector productivity development.

\section{Literature review}

Many studies have been done on the impact of fiscal policy on economic growth in developed and developing countries. Researches are oriented both in terms of revenue and in terms of expenditures as basic instruments of public finance. Regarding the research related to the effect of public spending on economic growth, the approach of the authors is oriented in different forms of study for different categories of public spending, either according to the functional division or according to budget classifications of expenditure. Although the objective of public spending policy is to achieve sustainable and equitable economic development, the results of empirical research show that the effects of public spending on economic growth are not linear, they are variable, where some findings supporting the theory that an expenditure growth reflects a decrease in economic growth, while some studies show that public spending has a positive effect on economic growth, and even some other studies show that there is no impact between public spending and economic growth. According to a study (Sattar, 1993), public spending has a positive impact on developing countries, but in developed countries, it has no impact on economic growth. Regarding the correlation between public expenditure and economic growth, the results are different in this respect as well, where many studies show that there is a positive correlation between public expenditure and economic growth (Ram, 1986), while other studies show that there is no correlation between expenditure public and economic growth. Both theoretical and empirical attitudes about the impact of public spending on economic growth scholars, politicians yet are divided and with opposite directions. 
In his work, the eminent professor Musgrave (Musgrave 1968) emphasizes that public economic policy has three basic functions, namely 1) The function of allocation - efficient allocation of resources, 2) The function of redistribution - to realize the distribution of income and wealth and 3) The function of stabilization - to achieve full employment, stability of the general level of economic growth.

What remains to be desired and clarified is to what extent public spending will boost economic growth and vice versa, at what level would public spending have a negative impact on economic growth?

Shantayanan Devarajan, Vinaya Swaroop, Heg-fu Zou (1996), investigate how a change in the structure of expenditures affects economic growth? Where in their study they include 43 developing countries for a period of 20 years (1970-1990). They conclude that an increase in current expenditures has a positive and significant effect on economic growth, while the relationship between capital expenditures and per capita growth is negative.

JR Barro (1999), in his research on the determinants of economic growth researched for 100 countries for the period 1960-1995, analyzing the public expenditures divided into current expenditures and investment expenditures, concluded that government public expenditures have a positive impact on growth, while consumer spending has a negative impact on economic growth and it has concluded that consumer spending should be kept low, and investment spending should be favored to ensure a higher increase.

C. Schaltegger and B. Torgler (2006), have measured the impact of budget expenditures which they have divided into operating expenditures and capital expenditures on the economic growth of Switzerland using data for a period of 20 years (1981-2001). The research results have shown that capital expenditures have a non-significant impact on economic growth while operating expenditures result in a negative impact.

During their research (Niloy Bose et al., 2007), analyzed the increasing effects of public spending on 30 developing countries for the period 1970-1980 with a focus on disaggregated budget expenditures. Their results show that the share of capital expenditures in GDP has a significant positive correlation with economic growth, while current expenditures are insignificant. Government investment in education, as well as general spending on education, is significant with economic growth.

Michael Connolly and Cheng Li (2016) in their research on government spending and economic growth in 34 OECD countries conclude that an increase in public spending in the social sphere results in a negative effect on economic growth. While government consumption expenditures and public investment do not have any significant effect on economic growth.

Dan Lupu, et all (2018), using the ARLD model, have measured the impact of public spending by function on economic growth for 10 selected countries in Southeast Europe for the period 19952015. The results of the research showed that expenditures on defense, public services, economy, and social welfare have a negative impact on economic growth, while public expenditures on education and health care have a positive impact.

Balaev A. (2018), analyzes the impact of general government productive and non-productive expenditures on the GDP growth rate in Russia, using the SVAR methodology, arrive at the results that an increase in the percentage of productive expenditures (national economy, education, and health) has a positive impact on the rate of economic growth, while an increase in the percentage of unproductive expenditures (national defense and social policy) has a negative effect on the pace of GDP growth.

\section{Research methodology and data}

The paper uses secondary data for the variables that are analyzed, which are collected by the Ministry of Finance of Kosovo, Central Bank of the Republic of Kosovo, Agency of Statistics, also uses data from International Financial Institutions such as the International Monetary Fund, World Bank, OECD, etc. Data for current expenditure, transfers, and subsidies, and capital expenditures are quarterly, collected from the Annual Reports of Consolidated Budget of the Republic of Kosovo for the period 2010-2018.

The collected data is processed using the SPSS automatic data processing method. The model used is multiple regression Ordinary Least Square (OLS) and Pearson Correlation. The conceptual variables are Gross Domestic Product (GDP), current expenditure, transfers and subsidies, capital expenditure.

The purpose of regression analysis is to construct the regression equation to predict the value of one variable (denoted by $\mathrm{Y}$ and called dependent variable) based on another variable (denoted by $\mathrm{X}$ and called independent variable) (Topxhiu, 2016).

The linear regression analysis has this formula: 


$$
\hat{\mathrm{Y}}=\mathrm{b}_{0}+\mathrm{b}_{1} \mathrm{X}+\mu
$$

The multiple linear regression equation is as follows:

$$
\hat{Y}=b_{0}+b_{1} X_{1}+b_{2} X_{2}+\ldots+b_{n} X_{n}+\mu
$$

Where $\mathrm{Y}$ is the predicted or expected value of the dependent variable,

$\mathrm{X}_{1}$ through $\mathrm{X}_{\mathrm{n}}$ are $\mathrm{p}$ distinct independent or predictor variables,

$\mathrm{b}_{0}$ is the value of $Y$ when all of the independent variables $\left(X_{1}\right.$ through $\left.X_{n}\right)$ are equal to zero, and $b_{1}$ through $b_{n}$ is the estimated regression coefficients.

Each regression coefficient represents the change in Y relative to a one-unit change in the respective independent variable. In the multiple regression situation, $b_{1}$, for example, is the change in $\mathrm{Y}$ relative to a one-unit change in $\mathrm{X}_{1}$, holding all other independent variables constant

The purpose of correlation analysis is to find the degree and intensity of the relationship between the dependent variable and the independent variable. The correlation coefficient $(r)$ can take any value between -1 and +1 , the formula for the correlation coefficient is as follows:

$$
r=\frac{\sum\left(x_{i}-\bar{x}\right) \cdot\left(y_{i}-\bar{y}\right)}{\sqrt{\sum\left(x_{i}-\bar{x}\right)^{2} \cdot\left(y_{i}-\bar{y}\right)^{2}}}
$$

The variables which are analyzed in the paper are Gross Domestic Product as a dependent variable and current expenditure, transfers and subsidies, capital expenditures as independent variables

\section{Result and discussion}

In this chapter, we present the results of the paper: the trend and structural analysis of the variables being researched, economic growth, and the main categories of budget expenditures (current expenditures, subsidies, and transfers, capital expenditures). Using the Pearson Correlation and OLS model, it discusses how budget expenditures affect the economic growth of Kosovo.

Figure1: Economic growth of Kosovo during the period 2008-2019

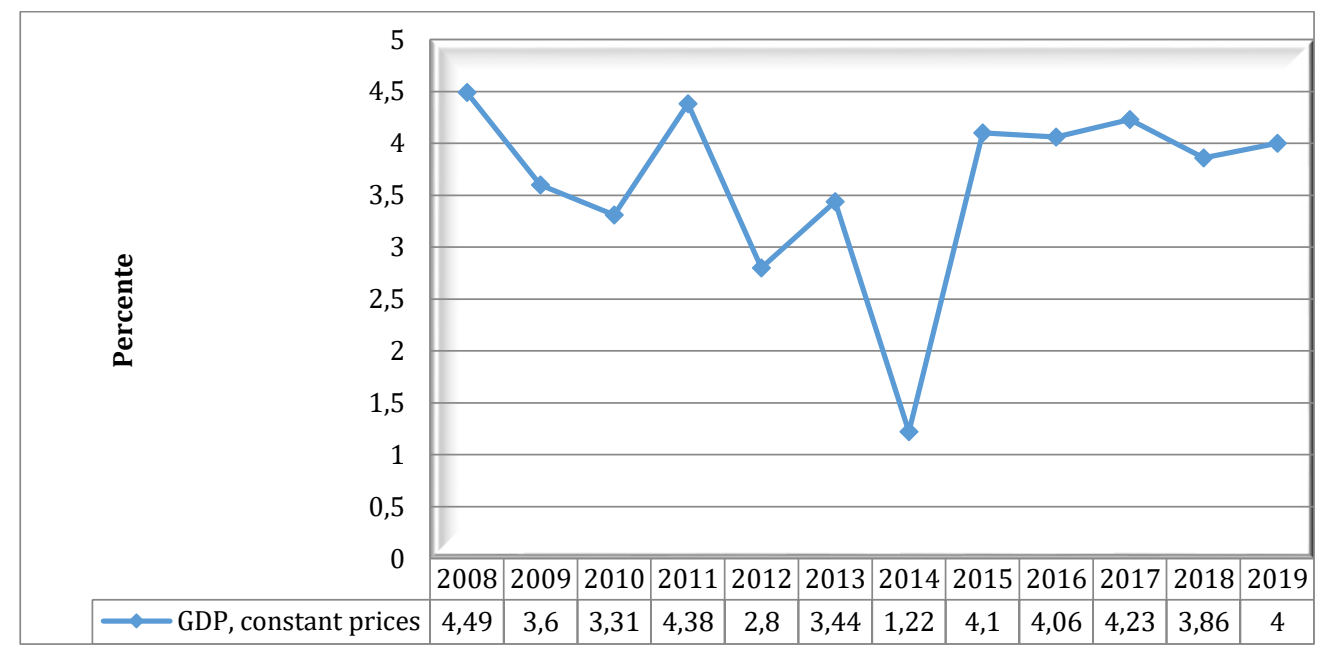

Source: International Monetary Fund, World Economic Outlook Database, October 2020; Author's calculations

The data presented in Graph. 1 show that the GDP trend for the analyzed period is not linear but with increasing and decreasing growth in the margins $4.49 \% 1.22 \%$ respectively, this oscillation is a consequence of some specific factors that have influenced in different years, such as the financial crisis of 2008 was also reflected in the slowdown in the economic growth of Kosovo, although the economy of Kosovo is not so much exposed to foreign economies severely affected by the financial crisis. Thus, in 2009 and 2010 there is a decrease in the economic growth of 19.8\% and 31\% respectively from 2008. The lowest economic growth in the analyzed period was recorded in 2014, at $1.22 \%$. Factors that contributed to the reduction of growth (Annual Report 2014 of CBK) were the decline in public investment of 22.3 percent and decline in foreign direct investment of 46.0 percent have influenced the real GDP growth to be lower than previous years. Also in this period, there has 
been an increase in consumption that has been driven by the increase in consumer loans, increase in wages and salaries in the public sector, increase in remittances, increase in subsidies and transfers. From 2015 there is a greater economic growth of $2.88 \%$ compared to 2014 reaching the level of $4.1 \%$ as a result of increased public infrastructure investments. Economic growth from 2015 to 2019 marks an average growth of $4.05 \%$.

Figure 2: GDP trend and budget expenditures

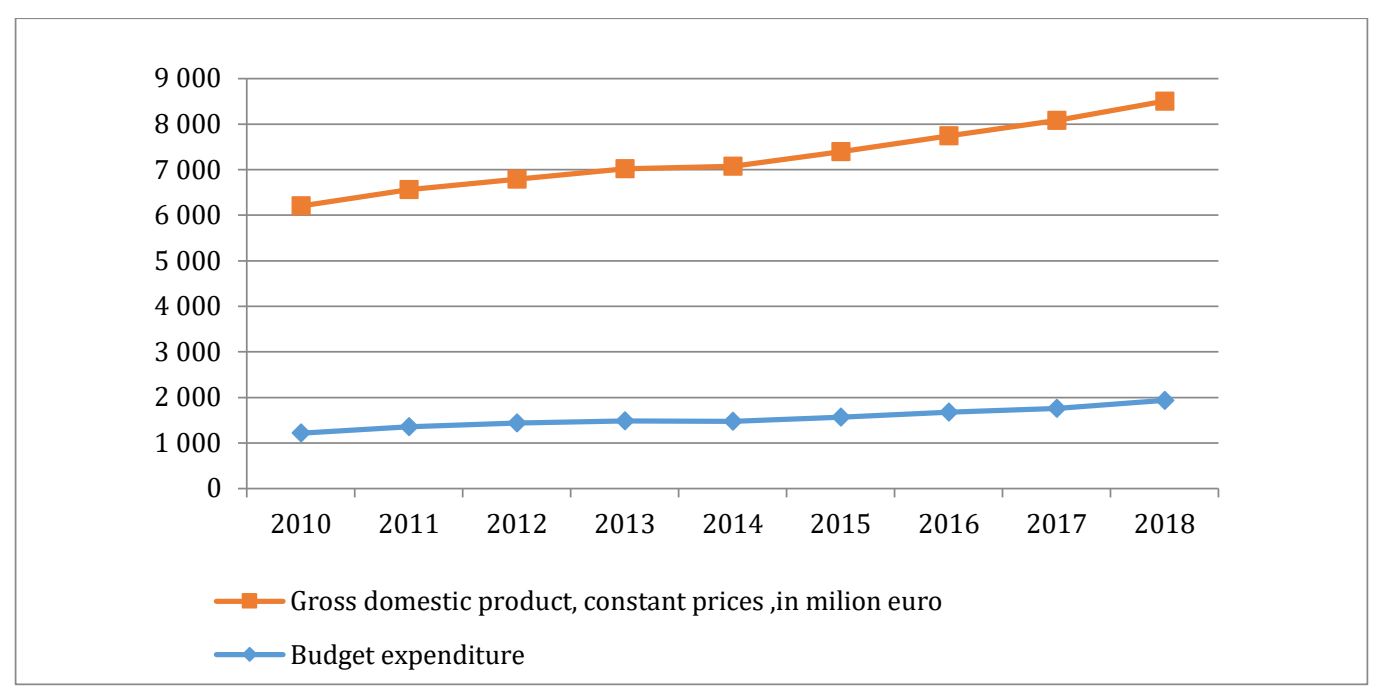

Source: Data from the Ministry of Finance of Kosovo and WOE calculated by the author

Government spending has risen in parallel with GDP growth. An increase in spending would be worrying if the economy of Kosovo did not grow at a sufficient rate. However, economic growth in Kosovo is stable, with an average rate of $4 \%$ in recent years and higher than other economies in the region. The ratio of expenditures to GDP shows a modest growth trend. The share of public expenditures to GDP in 2010 was $24.4 \%$ and by the end of this period, this ratio reached $29.5 \%$.

\subsection{Expenditures in the budget structure}

The structure budget expenditures of Kosovo consist of current expenditures (salaries and wages; goods and services; and utilities), transfers and subsidies, and capital expenditures (property, plant, equipment, and transfers).

\begin{tabular}{|c|c|c|c|c|c|c|c|c|c|}
\hline $\begin{array}{c}\text { Budget } \\
\text { expenditure }\end{array}$ & 2010 & 2011 & 2012 & 2013 & 2014 & 2015 & 2016 & 2017 & 2018 \\
\hline $\begin{array}{l}\text { Realization } \\
\text { Comparison }\end{array}$ & $1,215,640$ & $1,358,048$ & $1,438,417$ & $1,485,883$ & $1,474,986$ & $1,565,330$ & $1,675,493$ & $1,758,482$ & $1,936,927$ \\
\hline $\begin{array}{l}\text { with the } \\
\text { basic year } \\
2010\end{array}$ & - & $11.70 \%$ & $18: 30 \%$ & $22: 23 \%$ & $21: 33 \%$ & $28.77 \%$ & $37.82 \%$ & $44.65 \%$ & $59.33 \%$ \\
\hline $\begin{array}{l}\text { Horizontal } \\
\text { analysis }\end{array}$ & - & $11.70 \%$ & $5.90 \%$ & $3: 30 \%$ & $-0.70 \%$ & $6: 12 \%$ & 7:03\% & $4.95 \%$ & $10: 15 \%$ \\
\hline
\end{tabular}

Source: Data from the Ministry of Finance of Kosovo and WOE calculated by the author

Data from Table 1, show that during the period 2010-2018 the trend of current expenditures is increasing by $68 \%$ in 2018 compared to 2010 . Also, expenditures for subsidies and transfers mark an increasing trend of $120.4 \%$ in 2018 compared to 2010 While the capital expenditures realized, according to the data from the table, in different periods, depending on the realization of public investment capital projects, show different trends, so from the period 2010-2013 the trend is increasing as a result of the realization of infrastructure projects, most of the capital expenditures during 2010 were intended for investments in highway Morinë Merdar, which began to be built in April 2010. A result of this investment has explained the increase in capital expenditures in the following years until 2014. Since 2014, the trend of capital expenditures is rooted as a result of nonimplementation of some infrastructure projects with a more significant increase in 2018. 
Figure 3: Structure of budget expenditures for the period 2010-2018

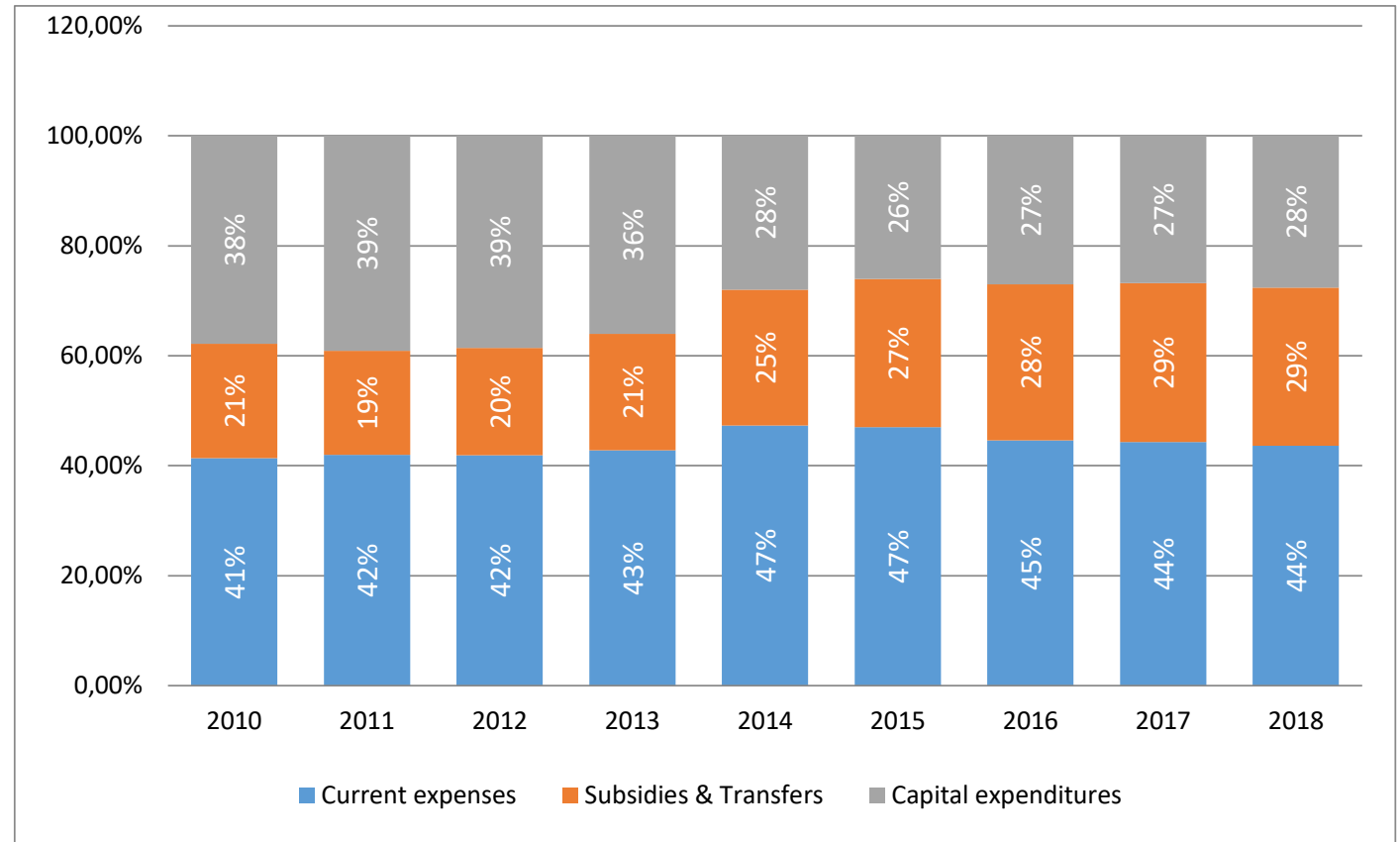

Source: Data from the Ministry of Finance of Kosovo and WOE calculated by the author

The data in Fig. 2 show the structure of budget expenditures by selected categories resulting in an almost linear trend of current expenditures participating from $41 \%$ in 2010 to $44 \%$ in 2018 in total budget expenditures. Capital expenditures in the period 2010 to 2014 have an average share of $36 \%$ in the general structure of expenditures, this is related to the implementation of infrastructure investment projects (construction of two highways, highway "Ibrahim Rugova", with a length of 130 $\mathrm{km}$, works of which started in 2010 and the highway "Arben Xhaferi" with a length of $65.6 \mathrm{~km}$, the construction of which began in mid-2014). The growing trend of capital expenditures is a reflection of the governing program with a focus on overall economic development, to meet the large needs of the country economy for capital investments.

\subsection{Interpretation of econometric results of the OLS model}

In this unit, we interpret and discuss the econometric results of research.

\begin{tabular}{cccc}
\multicolumn{2}{l}{ Table 2: Conceptual variables in the OLS Model } & & \\
\hline Model & Variables Entered & Variables removed & Method \\
\hline 1 & $\begin{array}{c}\text { Gross Domestic Product a } \\
\text { Current expenditure, transfers, and } \\
\text { subsidies, capital expenditures }\end{array}$ & & Enter
\end{tabular}

a. Dependent Variable: Gross Domestic Product

b. All requested variables entered

Source: Secondary data provided by the Ministry of Finance, data over the years, SPSS program author's calculations

Table 2 presents the conceptual variables used in the OLS model, where GDP is a dependent variable, while current expenditures, transfers, and subsidies, capital expenditures are independent variables.

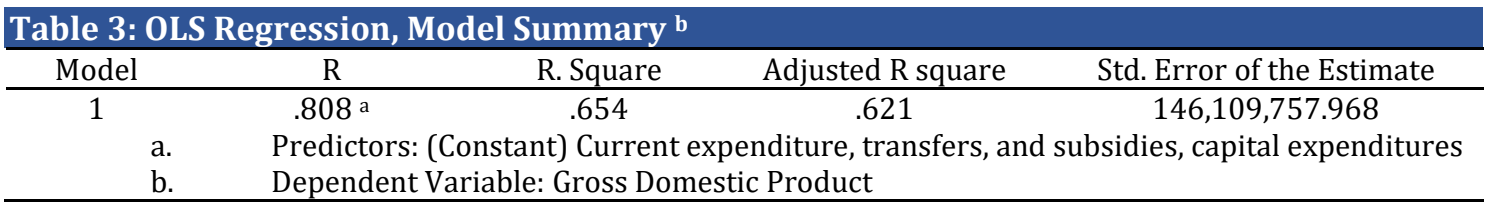

Source: Secondary data provided by the Ministry of Finance, data over the years, SPSS program author's calculations

In Table 3 we interpret the determination coefficient $\mathrm{R}$ that measures the importance of the model used. Based on the coefficient of determination it is seen that the model is important in our 
case the coefficient of determination $\mathrm{R}$ is 0.808 . The value of the coefficient of determination suggests that the model selected in this study is significant.

\begin{tabular}{|c|c|c|c|c|c|}
\hline \multirow{2}{*}{ Model } & \multicolumn{2}{|c|}{ Unstandardized Coefficients } & \multirow{2}{*}{$\begin{array}{c}\text { Standardized } \\
\text { Coefficients } \\
\text { Beta }\end{array}$} & \multirow[b]{2}{*}{$\mathrm{T}$} & \multirow[b]{2}{*}{ Sig. } \\
\hline & B & Std. Error & & & \\
\hline (Constant) & $666,164,801.672$ & $105,259,462.076$ & & 6329 & .000 \\
\hline Current expenditures & 2107 & 1239 & .369 & 1701 & .099 \\
\hline Transfers and subsidies & 3400 & 1535 & .438 & 2214 & .034 \\
\hline Capital expenditures & .304 & .515 & .073 & .595 & .559 \\
\hline
\end{tabular}

Source: Secondary data provided by the Ministry of Finance, data over the years, SPSS program author's calculations

Table 4 is very important where it presents the value of the variables in the model. We emphasize that the modified and adapted regression model in our case is a multifactorial regression model (OLS, where the independent variables are the realized budgeted expenditures (current expenditures; transfers and subsidies; and variable expenditures) which are expected to have an impact. The gross domestic product is defined as a dependent variable based on the p-value of the variables, from the table data we see that the independent variable-current costs are not significant since the $p$-value is $p=0.099$, the condition that $p \leq 0.05$ in our case is not reached. The independent variable, defined in the model as Transfers and subsidies, is statistically significant $\mathrm{p}=0.034$, as it is less than $\mathrm{p} \leq 0.05$ The third independent variable in our case named capital expenditures, is not significant since the $p$-value is 0.559 and is greater than $p \leq 0.05$ From this we can conclude that in cases where the independent variables result in a value of $p$ greater than 0.05 the effect of the variables is not explained but is insignificant in the model. Therefore in our case according to the terms of the model, current expenditures and capital expenditures have no impact on the economic growth of Kosovo. Whereas the variable transfers and subsidies are important in explaining the variation in Gross Domestic Product at the level of $5 \%$ of significance $(0.034<0.05)$.

\begin{tabular}{|c|c|c|c|c|c|}
\hline & & GDP & $\begin{array}{c}\text { Current } \\
\text { Expenditure }\end{array}$ & $\begin{array}{c}\text { Transfers } \\
\text { and } \\
\text { Subsidies }\end{array}$ & $\begin{array}{c}\text { Capital } \\
\text { Expenditure }\end{array}$ \\
\hline GDP & $\begin{array}{c}\text { Pearson } \\
\text { Correlation } \\
\text { Sig. (2-tailed) }\end{array}$ & 1 & & & \\
\hline Current Expenditure & $\begin{array}{c}\text { Pearson } \\
\text { Correlation } \\
\text { Sig. }(2 \text {-taied })\end{array}$ & $\begin{array}{l}.775^{* *} \\
.000\end{array}$ & 1 & & \\
\hline $\begin{array}{ll}\text { Transfers } & \text { and } \\
\text { Subsidies } & \end{array}$ & $\begin{array}{c}\text { Pearson } \\
\text { Correlation } \\
\text { Sig. (2-taied) }\end{array}$ & $\begin{array}{l}.772^{* *} \\
.000\end{array}$ & $\begin{array}{l}.842^{* *} \\
.000\end{array}$ & 1 & \\
\hline $\begin{array}{l}\text { Capital Expenditure } \\
{ }^{* *} \text { Correlation is signifi } \\
{ }^{*} \text { Correlation is signific }\end{array}$ & $\begin{array}{l}\text { Pearson } \\
\text { Correlation } \\
\text { Sig. }(2 \text {-taied) } \\
\text { at the } 0.01 \text { leve } \\
\text { at the } 0.05 \text { level }\end{array}$ & $\begin{array}{l}.395^{*} \\
.017 \\
\text { iled). } \\
\text { led). }\end{array}$ & $\begin{array}{l}.500^{* *} \\
.002\end{array}$ & $\begin{array}{l}.314 \\
.062\end{array}$ & 1 \\
\hline
\end{tabular}

Source: Secondary data provided by the Ministry of Finance, data over the years, SPSS program author's calculations

The table above shows the Pearson Correlation Matrix. The Pearson coefficient measures the relationship between only two variables where the coefficient takes values from -1 to +1 . The value of the Pearson coefficient $r=-1$ results in a negative correlation between the two variables, $r=+1$ the relationship between the variables is positive. When $r=0$, there is no relationship between the variables. From the results of Table 5, the correlation coefficient between GDP and current expenditure is $r=0.775$, so there is a strong positive and statistically significant relationship $(\mathrm{p}=$ 0.000 ) between GDP and current expenditure. The correlation coefficient between GDP and transfers and subsidies is $r=0.772$, so there is a strong positive, and statistically significant correlation $(\mathrm{p}=$ 0.000 ) between variables.

The correlation coefficient between GDP and capital expenditures is $r=0.395$, so there is a weak positive, and statistically significant relationship ( $\mathrm{p}=0.017$ ) between GDP and capital expenditures. 


\section{Conclusions and recommendations}

In the structure of public expenditures, capital expenditures have been a key element of the fiscal policy of the Government of the Republic of Kosovo since independence (2008), government authorities have applied a fiscal policy that favors public investment, especially in infrastructure to support economic growth in the country. While theoretically the impact of public investment on economic growth is assumed to be unquestionable, but numerous empirical studies have aimed to analyze the impact of public spending on economic growth, where some of them using cross-section data or time-series data have analyzed the effect of public expenditures in economic growth, while some studies have analyzed disaggregated public expenditures such as capital expenditures, education expenditures, health, etc. to economic growth. The findings of which are different, some have resulted only in weak links between public investment and economic growth, some even with a negative impact, etc. Even our findings in this paper, on the impact of public spending on economic growth, show a weak positive correlation of these variables, when the strongest positive correlation appears in current expenditures with GDP and transfers and subsidies with GDP. Although capital expenditures in the structure of general expenditures of the Republic of Kosovo for the analyzed period have a significant share as a result of major road infrastructure projects for the country implemented in the period 2010-2019, according to research results their effect on economic growth is not significant. Moreover, many public expenditure projects, such as those in the field of education or the field of investments in physical infrastructure, are characterized by long periods of implementation, when their effect on economic growth can be observed in a longer period. Therefore, using up-to-date data to link public spending to economic growth may not provide accurate results in the short term.

\section{Conflicts of Interest}

The author declares no conflict of interest.

\section{Citation information}

Miftari, F., Kida, N., \& Shala, N. (2021). The effect of public expenditures on economic growth of Kosovo: An econometrical analysis. Economics, Management and Sustainability, 6(1), 61-69. doi:10.14254/jems.2021.6-1.5

\section{Reference}

Agénor, P. R., \& Neanidis, K. C. (2011). The allocation of public expenditure and economic growth. The Manchester School, 79(4), 899-931. doi:10.1111/j.1467-9957.2011.02197.x

Balaev, A. (2018). The Impact of Public Expenditure Structure on Economic Growth in Russia. Economic Policy, 6, 8-35.

Barro, R .J. (1991). Economic growth in a cross-section of countries. Quarterly Journal of Economics, 106, 407-443. doi:10.2307/2937943.

Barro, R. J. (1999). Determinants of democracy. Journal of Political Economy, 107 (S6), S158- S183. doi: $10.1086 / 250107$

Bose, N., Haque, M. E., \& Osborn, D. R. (2007). Public expenditure and economic growth: A disaggregated analysis for developing countries. The Manchester School, 75(5), 533-556.

Connolly, M., \& Li, C. (2016). Government spending and economic growth in the OECD countries. Journal of Economic Policy Reform, 19(4), 386-395. doi:10.1080/17487870.2016.1213168

Devarajan, S., Swaroop, V., \& Zou, H. F. (1996). The composition of public expenditure and economic growth. Journal of monetary economics, 37(2), 313-344. doi:10.1016/S0304-3932(96)900392

Lupu, D., Petrisor, M. B., Bercu, A., \& Tofan, M. (2018). The impact of public expenditures on economic growth: A case study of Central and Eastern European countries. Emerging Markets Finance and Trade, 54(3), 552-570. doi:10.1080/1540496X.2017.1419127

Miftari, F., \& Ziberi, B. (2019). Public investment initiative, factors of economic growth-case of the Republic of North Macedonia. Knowledge, International Jurnal, 31(1). 
Ministry of Finance of Kosovo. (2019). Annual financial report, Budget of the Republic of Kosovo for years 2010-2019. Retrieved December 17, 2020, from www.mf.rks-gov.

Ram, R. (1986). Government size and economic growth: A new framework and some evidence from cross-section and time-series data. The American Economic Review, 76(1), 191-203. Retrieved December 17, 2020, from http://www.jstor.org/stable/1804136.

Sattar, Z. (1993). Public expenditure and economic performance: A comparison of developed and low-income developing economies. Journal of International Development,5(1), 27-49. doi: $10.2307 / 2937943$.

Schaltegger, C. A., \& Torgler, B. (2006). Growth effects of public expenditure on the state and local level: evidence from a sample of rich governments. Applied Economics, 38(10), 1181-1192. doi:10.1080/00036840500392334.

Topxhiu, R. M. (2016). Introduction to Statistics. Prishtina.

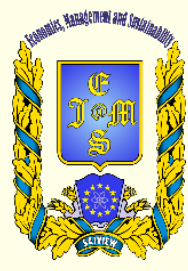

2016-2021, Economics, Management and Sustainability. All rights reserved.

This open access article is distributed under a Creative Commons Attribution (CC-BY) 4.0 license

You are free to:

Share - copy and redistribute the material in any medium or format Adapt - remix, transform, and build upon the material for any purpose, even commercially.

The licensor cannot revoke these freedoms as long as you follow the license terms.

Under the following terms:

Attribution - You must give appropriate credit, provide a link to the license, and indicate if changes were made.

You may do so in any reasonable manner, but not in any way that suggests the licensor endorses you or your use.

No additional restrictions

You may not apply legal terms or technological measures that legally restrict others from doing anything the license permits.

Economics, Management and Sustainability (ISSN: 2520-6303) is published by Scientific Publishing House "CSR", Poland, EU and Scientific Publishing House "SciView", Poland

Publishing with JEMS ensures:

- Immediate, universal access to your article on publication

- High visibility and discoverability via the JEMS website

- Rapid publication

- Guaranteed legacy preservation of your article

- Discounts and waivers for authors in developing regions

Submit your manuscript to a JEMS at http://jems.sciview.net or submit.jems@sciview.net 